\title{
Impact of environmental variables on abundance, growth and condition factor of Gymnarchus niloticus (Curvier, 1829) from Umueze-Ossissa lake system, Southern Nigeria
}

\author{
Agatha Arimiche Nwabueze ${ }^{*}$, Emmanuel Obiajulu Nwabueze ${ }^{2}$ \\ ${ }^{1}$ Department of Fisheries, Delta State University, Asaba Campus, Asaba, Nigeria \\ ${ }^{2}$ Department of Food Science and Technology, Delta State Polytechnic, Ozoro, Nigeria
}

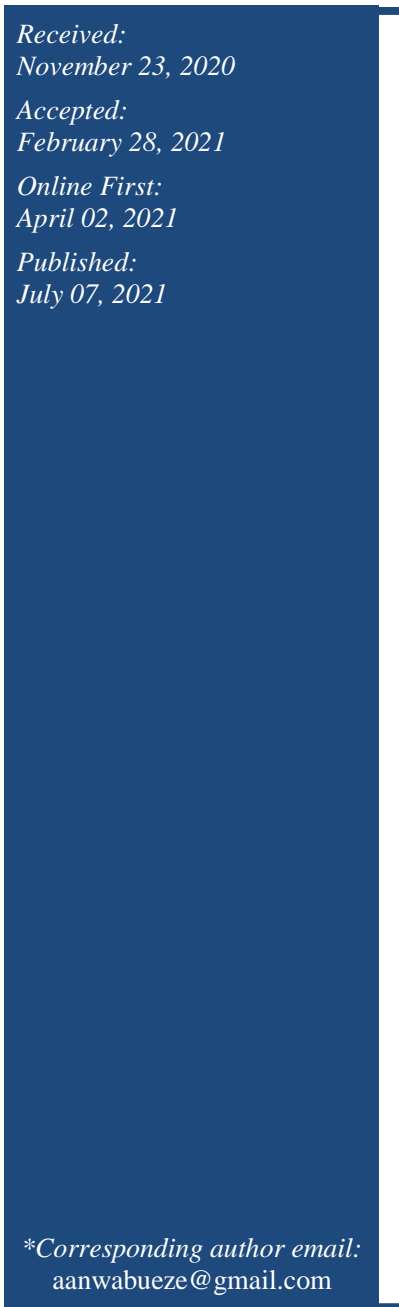

\begin{abstract}
The impact of environmental variables on abundance, growth and condition factor of Gymnarchus niloticus from two lakes in Umueze-Ossissa, Southern Nigeria was investigated to provide baseline information for effective management of the lakes. $G$. niloticus were collected fortnightly for a period of 12 months from fishermen who used set nets and percentage abundance determined. Length-weight relationship was used to determine growth pattern, condition factor and relative condition factor. Environmental variables such as water quality parameters affecting fish abundance were predicted with multiple regression analysis. G. niloticus was more abundant in Otu Lake than in Abiandu Lake. Male G. niloticus were significantly $(\mathrm{P}<0.05)$ more than female with female to male ratio of 1:1.8 and 1:1.7 in Otu and Abiandu lakes respectively. Gymnarchus niloticus showed negative allometric growth in the two lakes studied meaning that fish get slimmer as it increases in size. Condition factor of $G$. niloticus ranged from 0.24 to 4.09 and 0.59 to 3.73 and relative condition factor from 0.82 to 1.08 and from 0.92 to 1.12 in Otu and Abiandu Lakes respectively. High air temperature observed corresponded with high number of fish, while high amount of rainfall corresponded with low number of G. niloticus. Water quality parameters showed that depth, transparency, $\mathrm{DO}$ and BOD were significantly higher $(\mathrm{P}<0.05)$. The model used successfully predicted $G$. niloticus abundance. These findings are useful during planning for effective management of the lakes for sustainable economic and livelihood development of the area.
\end{abstract}

Keywords: Environment, Gymnarchus, Growth, Lake, Ossissa, Nigeria

\section{How to cite this:}

Nwabueze AA and Nwabueze EO, 2021. Impact of environmental variables on abundance, growth and condition factor of Gymnarchus niloticus (Curvier, 1829) from Umueze-Ossissa lake system, Southern Nigeria. Asian J. Agric. Biol. 2021(3): 202011567. DOI: https://doi.org/10.35495/ajab.2020.11.567

This is an Open Access article distributed under the terms of the Creative Commons Attribution 3.0 License. (https://creativecommons.org/licenses/by/3.0), which permits unrestricted use, distribution, and reproduction in any medium, provided the original work is properly cited.

\section{Introduction}

Fish is an important source of food and cheap protein for the over 186 million teaming population of Nigeria with abundant natural water resources (Ezeabasili et al., 2014; Idu, 2015) and some aquacultural production systems (Offem et al., 2010; Bradley et al. 2020) for fish food supplies from capture and culture 


\section{Agatha Arimiche Nwabueze and Emmanuel Obiajulu Nwabueze}

respectively. Human exploitation of these water resources causes environmental degradation affecting aquatic environment in the form of sub-lethal pollution resulting in negative effects on aquatic life (Adeyemo, 2003). The country now depends on importation of fish to meet up the gap between demand and supply of fish (Oluwarore, 2018; Nwokedi et al., 2020). Recently, there has been a growing interest in agricultural drive for increased food production, including fish production. The production of catfish, mainly Clarias and Heterobranchus species has been favoured (Adewumi and Olaleye, 2011) while researches are ongoing to identify other possible culturable fish species for subsistence and possibly commercial production (Agwumba et al., 1985; Ngueku, 2015).

Gymnarchus niloticus belongs to Family Gymnarchidae, a mono-specific genus. It is a common fish species in Nigeria and several West African countries. The fish is considered a highly priced ceremonial fish in Nigeria (Idodo-Umeh, 2003). The fish is not only an economic fish food but also of great socio-cultural importance in Nigeria (Ayoola and Abotti, 2010; Oladosun et al., 2012) which endears it as one of the most highly valued freshwater fishes in Nigeria. Despite its aquaculture potentials including rapid growth, high premium, tasteful, seasonal availability of wild growers (Kigbu et al., 2014), the supply of G. niloticus relies greatly on wild collection which is insufficient for its demands (Oladosun et al., 2012). A careful study of environmental factors influencing growth of G. niloticus is important for culture trials. Greshishchev et al. (2015) observed that great variability exist in most environmental variables and opined that these variables were related to different species of fish, including some endangered species. The influence of environmental factors such as temperature and depth on distribution pattern and diversities of fish species have been reported (Araoye, 2009; Nsor, 2016).

Interactions between the exogenous and endogenous factors on fish biometric parameters have remained an important issue in fish management practices. Ahmed et al. (2020) reported that exogenous and endogenous factors can affect haematologic parameters of fish which can act as biomarkers in toxicology and aquaculture studies. The interrelationships of ecological factors can have effect on the different fish species of the world. Jobling (2008) reported that environmental factors can affect fish growth while Eriegha and Ekokotu (2017) noted several factors which affect fish biometry as management practices, environmental conditions, feed quality, inherent genetic factor and physiological condition of the fish. The distribution, occurrence, aspects of biology and tolerable environmental conditions for survival of the fish species have been documented (Bennett, 1971; Riede, 2004; Akinsanya et al., 2007; Kakareko et al., 2005; Ara et al., 2011; Oluwale et al., 2019).

This study examines the impact of environmental variables on abundance, growth and condition factor of Gymnarchus niloticus, commonly known as Aba, Knife fish or trunk fish in Umueze-Ossissa lake system, Southern Nigeria. A baseline study of this nature is important as there are no literature on the lake system of Ossissa to provide useful information on growth conditions of Gymnarchus niloticus, which is important for sustainable fisheries management.

\section{Material and Methods}

\section{Description of study area}

The two lakes of study are Otu Lake and Abiandu Lake both located in Umueze, one of the major communities in Ossissa. Ossissa is a town with coordinates $5^{0} 57^{\prime}$ $00^{\prime \prime} \mathrm{N}$ and $6^{0} 30^{\prime} 00^{\prime \prime} \mathrm{E}$, located in Ndokwa East Local Government of Delta State, Nigeria. There are two natural lakes and several natural ponds in UmuezeOssissa, around where the Adofi River discharges into Oshimili River. Otu Lake is the largest of the two with approximately $0.8 \mathrm{~km}$ in width and $1.5 \mathrm{~km}$ in length and about $30 \mathrm{~m}$ deep. Abiandu Lake measures approximately $0.55 \mathrm{~km}$ in width, $0.7 \mathrm{~km}$ in length and about $18 \mathrm{~m}$ deep. The two lakes are situated north of Adofi River. Inhabitants of Umueze-Ossissa have to use canoe to cross the Adofi River in order to access the lakes or take a longer motor able route out of their community to access the lakes from the back end of Umueze-Ossissa. During periods of flood in the rainy season (between April and September) River Oshimili over flows its banks and forms a continuum with the two lakes. However, in the dry season (October to March), the two lakes are distinct from each other and the River Oshimili. There is an excessive growth of water hyacinth (Eichhornia crassipes) in the lakes, particularly Otu Lake. A vast portion of the water surface is covered up with Eichhornia crassipes. Other aquatic vegetation are also present but are suppressed by the growth of the water hyacinth. Fishermen normally paddle dug-out canoe in the lake by cutting their way through the water hyacinth bloom with 
machete to make for easy passage. Figure 1 shows the sampling stations at Otu Lake (Station 1) and Abiandu Lake (Station 2) at Umueze-Ossissa.

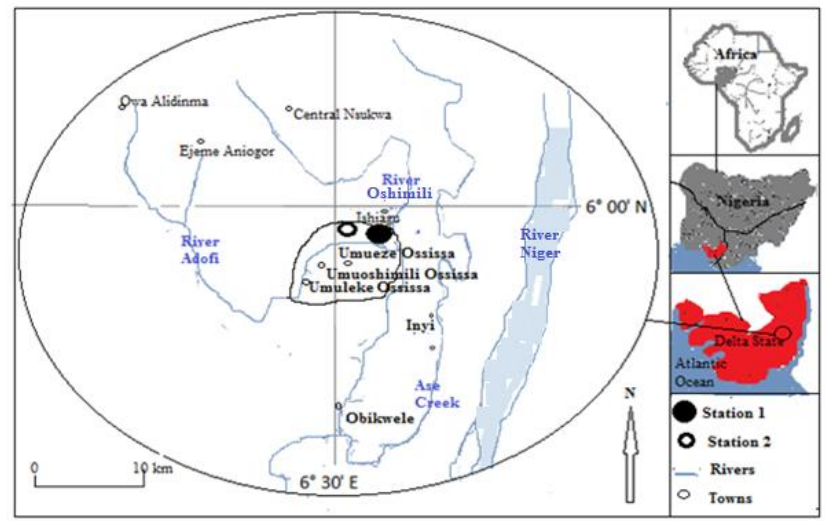

Figure-1. Study stations at Umueze Ossissa: Station1, Otu Lake and Station 2, Abiandu Lake (Inserts: Maps of Africa, Nigeria and Delta State).

\section{Collection of fish samples}

$G$. niloticus samples for studies were purchased fortnightly for twelve months from September, 2018 to August 2019 from fishermen who fished in the lakes using set net. Other fishes were also present in the lakes. A total of $529 \mathrm{G}$. niloticus samples used for the study were immediately kept in ice-chest and transported to the laboratory of the Department of Fisheries, Delta State University, Asaba Campus for biometric analysis. Fish samples were identified up to the species level (Reed et al., 1967; Idodo-Umeh, 2003).

\section{Biometry of fish samples}

Total length and standard length of fish samples were measured from the tip of the snout to the end of the caudal fin and peduncle respectively using a meter rule and recorded to the nearest $1.0 \mathrm{~cm}$ while weight measurements was done using a digital balance to 100 $\mathrm{g}$ accuracy. Then the girth length for all samples were taken.

\section{Water quality parameter}

Samples of water were collected between 7.00 and 10.00 hours using $250 \mathrm{ml}$ corked bottles the three points in each station based on ecological feature such as presence or absence on water of water hyacinth bloom and domestic activities and some selected physicochemical parameters determined. Temperature, dissolved oxygen (DO), hydrogen ion concentration $(\mathrm{pH})$ and conductivity were measured in-situ using Hanna portable instrument. DO meter, conductivity meter and $\mathrm{pH}$ meter were calibrated before use. For BOD, the dark sterile cocked bottle was left under water at the bank of the lake and BOD determined after 10 hours. Depth was measured with a graduated rope dropped from a canoe at the center of the lakes. Transparency was by secchi disc. Total dissolved solids (TDS) and Total suspended sediments (TSS) were determined according to methods described by APHA (2005).

\section{Growth condition}

The growth condition of G. niloticus was determined by length-weight relationship (LWR), condition factor $(\mathrm{K})$ and relative condition factor $(\mathrm{Kn})$. The $\mathrm{LWR}$ was determined from the formula: $\mathrm{W}=\mathrm{aLb}$. Using logarithmic transformation, parameters $\mathrm{a}$ and $\mathrm{b}$ in the formula were estimated as:

$$
\log W=\log a+b \log L
$$

where, $\mathrm{W}=$ Total body weight of fish, $\mathrm{L}=$ Total length of fish $(\mathrm{cm}), \mathrm{b}=$ growth exponent or regression coefficient and $\log \mathrm{a}=$ intercept on the $\mathrm{Y}$-axis.

The condition factor of $G$. niloticus was calculated from the length and weight relationship using Fulton's formula, given by LeCren (1951):

$$
\mathrm{K}=\mathrm{W} 100 / \mathrm{L}^{3}
$$

where $\mathrm{K}=$ Condition factor, $\mathrm{L}=$ Standard length of fish $(\mathrm{cm}), \mathrm{W}=$ Weight of fish $(\mathrm{g})$.

While relative condition factor, $\mathrm{K}_{\mathrm{n}}$ was calculated from the length-weight regression (LeCren, 1951) for both male and female fish. $\mathrm{K}_{\mathrm{n}}$ was established to assess the condition of $G$. niloticus fish samples under study. $\mathrm{K}_{\mathrm{n}}$ is given as:

$$
\mathrm{Kn}=\mathrm{w} / \mathrm{W}
$$

where, $w$ is observed weight of a fish at a given length and $\mathrm{W}$, expected weight of a fish of the same length.

\section{Environmental variables}

Impact of environmental variables on the abundance of $G$. niloticus was determined using multiple regression analysis. Environmental variables likely to affect abundance of $G$. niloticus were water quality parameters such as sub surface water temperature, depth, transparency, total suspended sediments (TSS), total dissolved solids (TDS), hydrogen ion concentration (pH), dissolved oxygen (DO), 


\section{Agatha Arimiche Nwabueze and Emmanuel Obiajulu Nwabueze}

biological oxygen demand (BOD), nitrate and phosphate levels. The regression model used was stated in equation form as:

$$
\begin{aligned}
& \mathrm{Y}=\mathrm{f}\left(\mathrm{X}_{1}, \mathrm{X}_{2}, \mathrm{X}_{3}, \mathrm{X}_{4}, \mathrm{X}_{5}, \mathrm{X}_{6}, \mathrm{X}_{7}, \mathrm{X}_{8}, \mathrm{X}_{9}, \mathrm{X}_{10}, \mathrm{e}\right) \\
& \begin{array}{l}
\mathrm{Y}=\mathrm{f}\left(\mathrm{temp}_{1},\right. \\
\text { transparency }_{3}, \mathrm{TSS}_{4}, \mathrm{TDS}_{5}, \mathrm{pH}_{6}, \mathrm{DO}_{7}, \mathrm{BOD}_{8}, \mathrm{Nitrate}_{9}, \mathrm{ph}
\end{array} \\
& \text { osphate } \left._{10}, \mathrm{e}\right)
\end{aligned}
$$

Where: $\quad \mathrm{Y}=$ dependent variable $(G$. niloticus abundance)

$$
\begin{aligned}
& \mathrm{X}_{1} \ldots \mathrm{X}_{10}=\text { independent variables } \\
& \mathrm{e}=\quad \text { Random Error } \\
& \text { (Udoh and Nyienakuna, 2008). }
\end{aligned}
$$

Three functional forms of the model such as linear, semi-log and double-log functions were used (Almeida et al., 2001). The one with the best fit was used as the lead function based on having the highest value of the coefficient of multiple determination, highest number of significant variables and conformity to a priori expectations. Abundance of $G$. niloticus was inputted as the dependent variable while water quality parameters were taken as the independent variables.

\section{Statistical analysis}

Data collected were analyzed by descriptive statistics, correlation, linear and multiple regression analyses at $\mathrm{P}<0.05$ using SPSS 17.

\section{Results}

Gymnarchus niloticus had a peak of abundance in Station 1 in the month of January while in Station 2, G. niloticus was more abundant in November, December and January during the study. Male fish were more in number with a ratio of female to male of 1.76:1 and 1.66:1 for G. niloticus from Stations 1 and 2 respectively. G. niloticus was more abundant in Station 1 than in Station 2. Fish sampled from Station 1 amounted to $67.3 \%$ of all G. niloticus collected during the study. Figure 2 shows percentage abundance of G. niloticus in Otu Lake (Station 1) and Abiandu Lake (Station 2). A comparison of rainfall amount and prevailing air temperatures of the study area shows that rainfall was higher in August and > September, while temperature was higher in February followed by January. The high temperature observed in January corresponded with high number of fish, while high amount of rainfall corresponded with low number of G. niloticus harvested (Figure 3).
G. niloticus from Station 1, Otu Lake, ranged in total length from $25 \mathrm{~cm}$ to $136 \mathrm{~cm}$ and body weight from $520 \mathrm{~g}$ to $6,900 \mathrm{~g}$. While in Station 2, G. niloticus ranged from $24 \mathrm{~cm}$ to $80 \mathrm{~cm}$ with weight ranging from of $500 \mathrm{~g}$ to $3,800 \mathrm{~g}$. The length-weight relationships of G. niloticus is presented in Table 1. Gymnarchus niloticus showed allometric growth in the two lakes studied because all exponential 'b' value obtained were less than $3(b<3)$ for male and female fish as well as for combined sexes of fish. A high $R^{2}$ was obtained in all groups of $G$. niloticus. The regression equation of body weight on total length of both sexes of $G$. niloticus in Stations 1 and 2 were $y=1.051+1.321 \mathrm{x}$ and $\mathrm{y}=0.26+1.809 \mathrm{x}$ respectively (Figures 4 and 5).

Table-1. Length-weight and parametric relationships of G. niloticus from study lakes in Ossissa

\begin{tabular}{|c|c|c|c|c|c|c|c|c|}
\hline Stations & & $\mathbf{N}$ & $\boldsymbol{A}$ & $\boldsymbol{B}$ & S.E.(b) & $\mathbf{R}$ & $\boldsymbol{R}^{2}$ & $\begin{array}{c}\boldsymbol{P} \\
\text { value }\end{array}$ \\
\hline \multirow{2}{*}{$\begin{array}{c}\text { Otu } \\
\text { Lake }\end{array}$} & Male & 227 & 1.012 & 1.332 & 0.040 & 0.911 & 0.829 & 0.000 \\
\cline { 2 - 9 } & Female & 129 & 1.143 & 1.289 & 0.038 & 0.950 & 0.902 & 0.000 \\
\cline { 2 - 9 } & $\begin{array}{c}\text { Both } \\
\text { sexes }\end{array}$ & 356 & 1.051 & 1.321 & 0.031 & 0.916 & 0.839 & 0.000 \\
\hline \multirow{2}{*}{$\begin{array}{c}\text { Abiandu } \\
\text { Lake }\end{array}$} & Male & 108 & 0.241 & 1.831 & 0.048 & 0.965 & 0.931 & 0.003 \\
\cline { 2 - 9 } & Female & 65 & 0.297 & 1.767 & 0.165 & 0.803 & 0.645 & 0.266 \\
\cline { 2 - 9 } & $\begin{array}{c}\text { Both } \\
\text { sexes }\end{array}$ & 173 & 0.260 & 1.809 & 0.074 & 0.883 & 0.779 & 0.033 \\
\hline
\end{tabular}

Figure-2. Percentage abundance of G. niloticus in

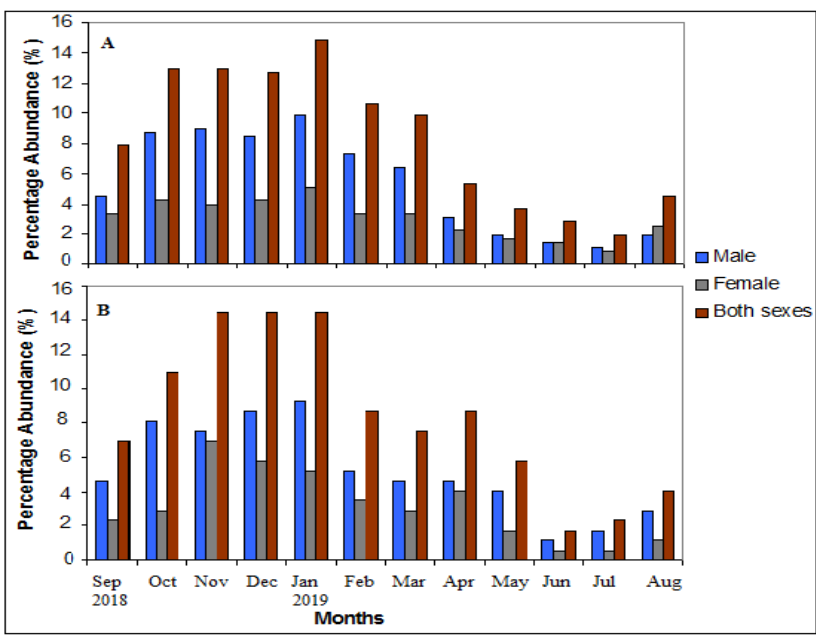

Otu Lake (A) and Abiandu Lake (B). 
Table-2. Mean (S.D.) Condition factor (K) and relative condition factor (Kn) of Gymnarchus niloticus from Otu and Abiandu Lakes

\begin{tabular}{|l|c|c|}
\hline & $\begin{array}{c}\text { Station 1 } \\
\text { Otu }\end{array}$ & $\begin{array}{c}\text { Station 2 } \\
\text { Abiandu }\end{array}$ \\
\hline K male & $1.55 \pm 1.29$ & $1.41 \pm 1.02$ \\
\hline K female & $1.81 \pm 1.24$ & $1.80 \pm 1.31$ \\
\hline K both sexes & $1.70 \pm 1.26$ & $1.61 \pm 1.17$ \\
\hline Kn male & $1.07 \pm 0.27$ & $0.98 \pm 0.17$ \\
\hline Kn female & $1.08 \pm 0.19$ & $0.96 \pm 0.25$ \\
\hline Kn both sexes & $1.08 \pm 0.24$ & $0.97 \pm 0.21$ \\
\hline
\end{tabular}

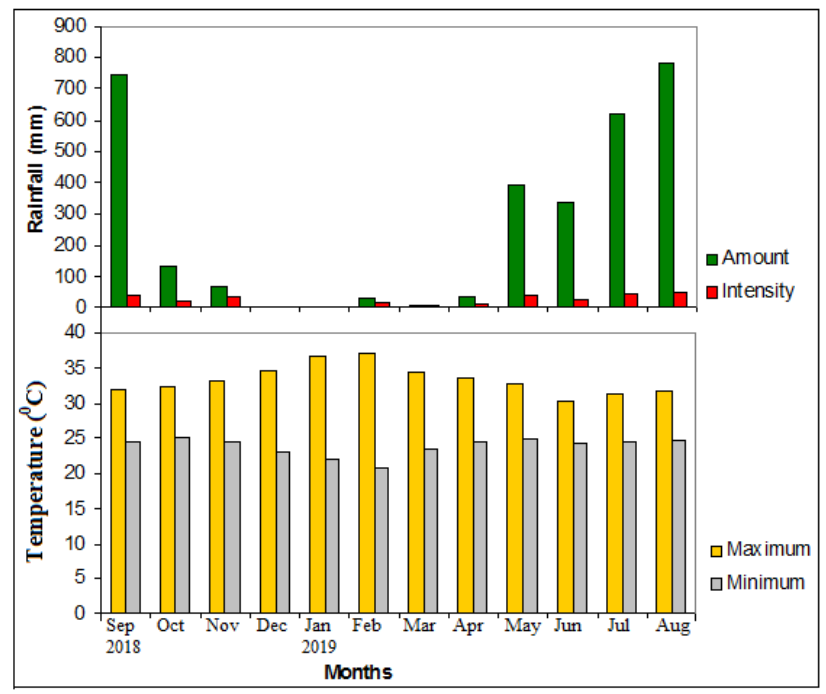

Figure-3. Prevailing Rainfall and Temperature Patterns of Asaba over study area.

Table-3. Mean (SD) water quality parameters of study stations

\begin{tabular}{|l|c|c|}
\hline \multicolumn{1}{|c|}{$\begin{array}{c}\text { Water quality } \\
\text { Parameters }\end{array}$} & $\begin{array}{c}\text { Station 1 } \\
\text { Otu Lake }\end{array}$ & $\begin{array}{c}\text { Station 2 } \\
\text { Abiandu Lake }\end{array}$ \\
\hline Temperature ${ }^{0} \mathrm{C}$ & $27.96 \pm 0.57 \mathrm{a}$ & $27.91 \pm 0.38 \mathrm{a}$ \\
\hline Depth $(\mathrm{m})$ & $24.01 \pm 1.56 \mathrm{~b}$ & $16.00 \pm 0.97 \mathrm{a}$ \\
\hline Transparency $(\mathrm{cm})$ & $28.11 \pm 7.12 \mathrm{~b}$ & $16.00 \pm 1.09 \mathrm{a}$ \\
\hline Total suspended sediments $(\mathrm{mg} / \mathrm{L})$ & $0.08 \pm 0.04 \mathrm{a}$ & $0.08 \pm 0.04 \mathrm{a}$ \\
\hline Total dissolved solids $(\mathrm{mg} / \mathrm{L})$ & $0.09 \pm 0.02 \mathrm{a}$ & $0.08 \pm 0.04 \mathrm{a}$ \\
\hline pH & $6.61 \pm 0.14 \mathrm{a}$ & $6.67 \pm 0.06 \mathrm{a}$ \\
\hline DO $(\mathrm{mg} / \mathrm{L})$ & $10.08 \pm 0.46 \mathrm{~b}$ & $7.57 \pm 0.44 \mathrm{a}$ \\
\hline BOD $(\mathrm{mg} / \mathrm{L})$ & $8.48 \pm 0.70 \mathrm{~b}$ & $7.18 \pm 0.49 \mathrm{a}$ \\
\hline Nitrate $(\mathrm{mg} / \mathrm{L})$ & $5.71 \pm 1.15 \mathrm{a}$ & $3.18 \pm 0.41 \mathrm{a}$ \\
\hline Phosphate $(\mathrm{mg} / \mathrm{L})$ & $39.46 \pm 1.89 \mathrm{a}$ & $45.07 \pm 5.79 \mathrm{a}$ \\
\hline
\end{tabular}

Means (+S.D) on same row with different letters are significantly different at $\mathrm{P}<0.05$.

Condition factor, $\mathrm{K}$ of $G$. niloticus in Otu Lake ranged from 0.24 to 4.06 for males and from 0.26 to 4.09 for females. In Abiandu Lake, condition factor was between 0.59 and 3.73 for males and between 0.79 and 3.64 for female fish respectively. For relative condition, $\mathrm{K}_{\mathrm{n}}$ of Otu Lake ranged in values from 0.82 to 1.07 and from 0.96 to 1.08 for male and female fish. While in Abiandu Lake male ranged from 0.90 to 1.19 and female from 0.97 to 1.12 respectively (Table 2 ). The water quality parameters analyzed (Table 3 ) show that depth, transparency, DO and BOD were significantly higher $(\mathrm{P}<0.05)$ in Station 1 than in Station 2.

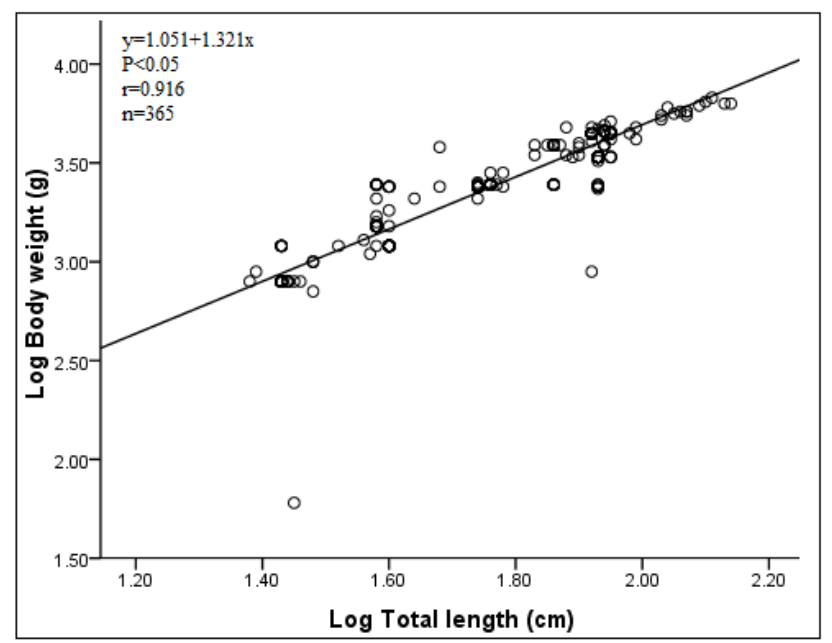

Figure-4. Length-weight relationship of $G$. niloticus from Otu Lake, Umueze-Ossissa (combined sexes).

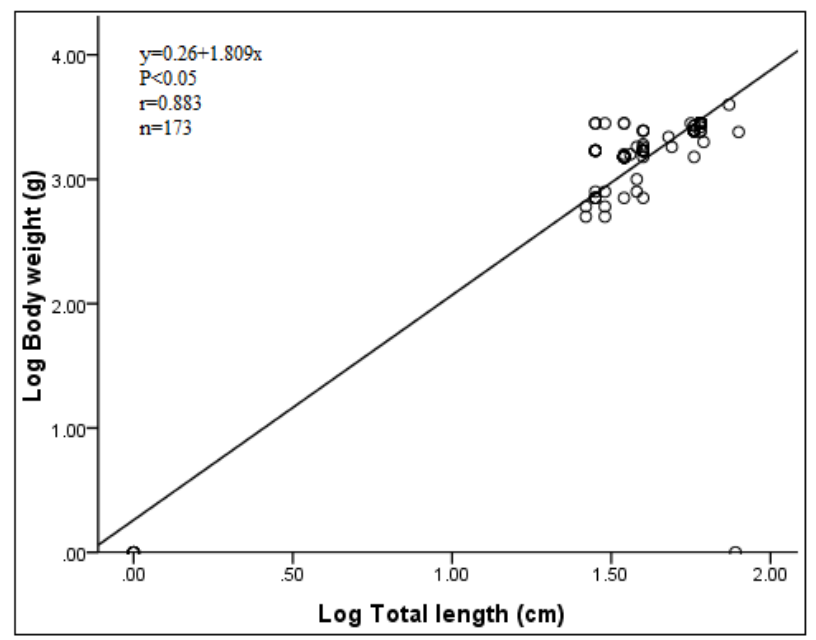

Figure-5. Length-weight relationship of Gymnarchus niloticus from Abiandu Lake, Umueze-Ossissa (combined sexes).

The R-square $\left(R^{2}\right)$ of 0.988 and 0.957 were obtained for Stations 1 and 2 respectively. The F value of 8.008 and 2.241 were significant $(\mathrm{P}<0.05)$ with a $P<0.209$ and $P<0.481$ for Stations 1 and 2 respectively. Results of multiple regression analyses of impact of 
environmental variables on abundance of G. niloticus in Stations 1 and 2 are presented in Tables 4 and 5.

Table-4. Results of multiple regression analysis on determinants of $G$. niloticus abundance in Station 1, Otu Lake.

\begin{tabular}{|l|c|c|c|c|}
\hline \multicolumn{1}{|c|}{ Independent variables } & Coefficients & ${ }_{ \pm}$S. E & T & P value \\
\hline Constant & -456.415 & 348.867 & -1.308 & 0.415 \\
\hline Water temperature $\left({ }^{0} \mathrm{C}\right)$ & 8.594 & 4.098 & 2.097 & $0.283^{*}$ \\
\hline Depth $(\mathrm{m})$ & 1.039 & 2.392 & 0.434 & 0.739 \\
\hline Transparency $(\mathrm{cm})$ & 0.252 & .140 & 1.809 & $0.321^{*}$ \\
\hline Total suspended sediments (mg/L) & -80.818 & 327.555 & -0.247 & 0.846 \\
\hline Total dissolved solids (mg/L) & -42.422 & 111.013 & -0.382 & 0.768 \\
\hline pH & 22.310 & 44.742 & 0.499 & 0.706 \\
\hline Dissolved oxygen (mg/L) & -10.296 & 12.020 & -0.857 & 0.549 \\
\hline Biological oxygen demand (mg/L) & 7.646 & 6.868 & 1.113 & $0.466^{*}$ \\
\hline Nitrate (mg/L) & 3.210 & 7.668 & 0.419 & 0.748 \\
\hline Phosphate (mg/L) & 1.152 & 3.537 & 0.326 & 0.800 \\
\hline
\end{tabular}

*significant at $\mathrm{P}<0.05$; Source: Field survey, 2019.

Table-5. Results of multiple regression analysis on determinants of $\boldsymbol{G}$. niloticus abundance in Station 2, Abiandu Lake.

\begin{tabular}{|l|c|c|c|c|}
\hline \multicolumn{1}{|c|}{ Independent variables } & Coefficients & ${ }_{ \pm}$S. E & T & $\begin{array}{c}\boldsymbol{P} \\
\text { value }\end{array}$ \\
\hline Constant & 95.829 & 219.262 & 0.437 & 0.738 \\
\hline Water temperature $\left({ }^{0} \mathrm{C}\right)$ & 1.733 & 7.372 & 0.235 & 0.853 \\
\hline Depth (m) & -5.963 & 6.183 & -0.964 & 0.512 \\
\hline Transparency $(\mathrm{cm})$ & 0.114 & 0.207 & 0.552 & 0.679 \\
\hline Total suspended sediments (mg/L) & 17.126 & 59.650 & 0.287 & 0.822 \\
\hline Total dissolved solids (mg/L) & 14.607 & 39.268 & 0.372 & 0.773 \\
\hline pH & -8.615 & 39.405 & -0.219 & 0.863 \\
\hline Dissolved oxygen $(\mathrm{mg} / \mathrm{L})$ & 11.783 & 7.237 & 1.628 & $0.351 *$ \\
\hline Biological oxygen demand $(\mathrm{mg} / \mathrm{L})$ & -9.305 & 22.533 & -0.413 & 0.751 \\
\hline Nitrate $(\mathrm{mg} / \mathrm{L})$ & -13.765 & 26.266 & -0.524 & 0.693 \\
\hline Phosphate (mg/L) & 0.678 & 0.343 & 1.981 & $0.298^{*}$ \\
\hline
\end{tabular}

*significant at $\mathrm{P}<0.05$; Source: Field survey, 2019.

\section{Discussion}

Gymnarchus niloticus was more abundant in Otu Lake than in Abiandu Lake. There were more male than female G. niloticus in this study with female to male ratio of $1: 1.8$ and 1:1.7 in Otu and Abiandu lakes respectively. Opadokun and Ajani (2015) reported a similar ratio and noted that this was a departure from the theoretical 1:1 ratio expected in nature. Evolutionary studies have shown that sex ratios can be highly variable with deviations and biases in both male and female fish occurring in natural environments (McKellar et al., 2009; Liker et al., 2013; Sowersby et al., 2020).

The influence of prevailing environmental temperatures, rainfall amount and intensity of Asaba being under the same tropical rainfall zone with the study area was compared with the percentage abundance of G. niloticus in the study stations. It was observed that rainfall was higher in August and > September, while temperature was higher in February followed by January. The high temperature observed in January corresponded with high number of fish, while high amount of rainfall corresponded with low number of $G$. niloticus harvested. Fish abundance have been reported to be affected by temperature and rainfall pattern as well as other environmental factors (Ayub, 2010; Castillo-Rivera, 2013). These relationships could be attributed to the fact that a higher temperature can result in a reduction in water level and with reduced water level the fishes are usually more available for harvesting. This may have accounted for the higher abundance of fish species in the dry season and the lower abundance in the rainy season.

Depth, transparency, dissolved oxygen and biological oxygen demand were significant water quality parameters observed in the two lakes. Water quality parameters are interrelated in their effects in the lakes. While depth may have encouraged luxuriant growth of roots of Eichhornia crassipes in Otu Lake especially, the resulting bloom may have led to a reduction in transparency and dissolved oxygen levels. Otu lake is definitely deeper and less transparent with heavy growth of Eichhornia crassipes. This may have impacted on the oxygen content of the lake resulting in a difference when compared with Abiandu Lake. The bloom of Eichhornia crassipes observed was also a reason fishermen were observed to have problems of navigating their canoe during fish sampling. The infestation of ponds with Eichhornia crassipes have been reported to have both positive and negative effects on fish. While the roots of Eichhornia crassipes provided nesting grounds and increase fish abundance and diversity, water parameters such as dissolved oxygen, nitrate and phosphorus concentrations were significantly reduced (Villamagna and Murphy, 2010; Yongo et al., 2017). Abnormal levels in abiotic factors result in stress in fish which can prevent or reduce fish growth. Wahl and Claramunt (2000) reported that abiotic factors can 


\section{Agatha Arimiche Nwabueze and Emmanuel Obiajulu Nwabueze}

determine larval fish growth rates and hence fish recruitment and that factors such as temperature and lake size were important in explaining growth of fish species. Mahavadiya et al. (2018) opined that stress can also prevent fish from feeding. Daga et al. (2012) also observed that abiotic variables such as total phosphorus, dissolved oxygen and conductivity, temperature and $\mathrm{pH}$ determine the distribution of fish assemblages and that an understanding of the relationship between species and their environment is crucial for conservation.

The allometric growth of G. niloticus observed in this study indicates that fish growth is faster in length than in weight. A value of ' $b$ ' lower than 3 , that is, when ' $b$ ' $<3$, is indicative of negative allometry in growth pattern. This means that fish get slimmer as it increases in size. Similar low 'b' values have been reported for Bagrus bayad male from River Adofi (Nwabueze and Garba, 2015). Jisr et al. (2018) reported that when ' $b '<3$, there is negative allometry and when ' $b$ '>3 is positive allometry, whereas isometric growth occurs when ' $b$ ' $=3$. Length-weight relationships and relative condition factor are indicators of general well being of fish and are of great importance in the assessment of any fishery since it provide information about the growth of the fish and fitness of fish (Jisr et al., 2018). Condition factor describes the body condition of fish, which is a key indicator of health at individual or population level (Peig and Green, 2009). It is also, closely related to growth (Lloret et al., 2002) and survival (Peig and Green, 2009; 2010). In this study, the relative condition, $\mathrm{K}_{\mathrm{n}}$, obtained for G. niloticus in both Otu and Abiandu Lakes ranged in values from 0.82 to 1.19 . These findings are acceptable since good fish growth condition occurs when $\mathrm{K}_{\mathrm{n}} \geq 1$, while the fish can be said to be in poor growth condition compared to an average individual with the same length when $K_{n}<1$ (Jisr et al., 2018).

During period of floods in the rainy season, mixing of fish from the water bodies which form a continuum cannot be completely ruled out because fishes are free to swim about within the water bodies. There is therefore a possibility of fishes from the two lakes mixing. However, over the years, it has been noted that fishes from Otu lake are clearly darker in colour than fishes from nearby water bodies, probably due to the abundance of macrophytes, depth and darker colour of the water. Pond coloration have been reported to signify nutrient load and an abundance of algae and macrophytes. Mane et al. (2017) noted that pond colour is associated with the promotion or abundance of desirable plankton species which plays a vital role in extensive and semi-intensive fish culture practices. Also, fish samples were harvested from set nets in different locations of the two lakes, thus representing fish samples from the individual lakes.

The $\mathrm{R}$-square $\left(R^{2}\right)$ obtained in the analyses shows that the model used was a good fit, implying that $98.8 \%$ and $95.7 \%$ of $G$. niloticus abundance was accounted for by the independent variables. In Station 1, water temperature, transparency and BOD were significant variables while in Station 2, DO and phosphate were significant. These independent variables are likely important factors affecting the abundance of $G$. niloticus in the study stations. These variables were also significant water quality parameters observed in this study. Total suspended sediments, total dissolved solids and dissolved oxygen obtained for Station 1 and depth, $\mathrm{pH}$, biological oxygen demand and nitrate obtained for Station 2, had negative coefficients, thus, implies that increases in the magnitude of these variables may lead to a reduction in the abundance of $G$. niloticus. The positive coefficients are indicative of factors that could increase abundance of G. niloticus. These findings are important baseline information for effective management of the lakes. Francis et al. (2005) successfully used predictive models to predict the effect of environmental factors on fish presence and abundance and opined that for independent data set the predictors could be useful for guiding the management of human activities in planning intensive process-based research.

\section{Conclusion}

This study has shown that G. niloticus exhibited negative allometric growth pattern in the two lakes studied. Condition factor and relative condition factor were within limit for acceptable good fish growth. Environmental variables such as air temperature, rainfall amount and water quality parameters impacted on abundance of G. niloticus. An understanding of the relationship between this fish species and its environment is crucial for conservation to determine fish growth, survival and distribution patterns. These findings are useful baseline information on $G$. niloticus biometric parameters needed during planning for effective management of the lakes for sustainable economic and livelihood development of the area. 
Disclaimer: None.

Conflict of Interest: None.

Source of Funding: None.

\section{References}

Adewumi AA and Olaleye VF, 2011. Catfish culture in Nigeria: Progress, prospects and problems. Afr. J. Agric. Res. 6(6):1281-1285.

Adeyemo OK, 2003. Consequences of Pollution and Degradation of Nigerian Aquatic Environment on Fisheries Resources. The Environmentalist. 23(4):297-306.

DOI:10.1023/B:ENVR.0000031357.89548.fb

Agwumba A, Ezenwa BB, Alegbeleye $\mathrm{O}$ and Anyanwu P, 1985. Culturable fish seeds in Nigerian waters: A research survey (1978-1985). In: 4th Annual Conference of the Fisheries Society of Nigeria (FISON), 26-29 November, 1985, Port-Harcourt, Nigeria. pp. 99-112.

Ahmed I, Reshi QM and Fazio F, 2020. The influence of the endogenous and exogenous factors on haematological parameters in different fish species: a review. Aquacult. Int. 28:869-899. https://doi.org/10.1007/s10499-019-00501-3.

Akinsanya B, Hassan AA and Otubanjo OA, 2007. A comparative study of the parasitic helminth fauna of Gymnarchus niloticus (Gymnarchidae) and Heterotis niloticus (Osteoglossidae) from Lekki Lagoon, Lagos, Nigeria. Pak. J. Biol. Sci. 10 (3): 427-432.

Almeida OJ, McGrath D, Arima E and Ruffino ML, 2001. Production Analysis of Commercial Fishing in the Lower Amazon. J. Fish. Manage. Ecol. 8: 198-214.

APHA, 2005. Standard method for the examination of water and waste water (21st Edition) American Public Health Association, USA. pp. 62-68.

Ara R, Arshad A, Musa L, Amin SMN and Kuppan P, 2011. Feeding habits of larval fishes of the family Clupeidae (Actinopterygii: Clupeiformes) in the Estuary of River Pendas, Johor, Malaysia. J. Fish. Aquat. Sci. 56: 816-821.

Araoye PA, 2009. Physical factors and their influence on fish species composition in Asa lake, Ilorin, Nigeria. Revista de Biologia Tropical. 57(1-2): 167-175.

Ayoola SO and Abotti CE, 2010. Morphology of the amba knife fish (Gymnarchus niloticus

(Curvier, 1829). World J. Fish. Marine Sc. 2(5):
354-356.

Ayub Z, 2010. Effect of temperature and rainfall as components of climate change on fish and shrimp catch in Pakistan. J. Transdiscipl. Environ. Stud. 9(1): 1-9.

Bennett MVL, 1971. Electric Organs. In: Fish Physiology. Hoar, W. S. and D. J. Randall (Eds.). 9th Ed. Academic Press, London, UK. pp. 347-491.

Bradley B, Byrd KA, Atkins M, Isa S, Akintola SL, Fakoya KA, Ene-Obong $\mathrm{H}$ and Thilsted SH, 2020. Fish in Food systems in Nigeria: A Review. Penang Malaysia: WorldFish. Program Report: 2020-06. CGIAR Research Program on Fish.

Castillo-Rivera M, 2013. Influence of Rainfall Pattern in the Seasonal Variation of Fish Abundance in a Tropical Estuary with Restricted Marine Communication. J. Water Resour. Protec. 5(3):311-319. DOI: 10.4236/jwarp.2013.53A032

Daga VS, Gubiani EA, Cunico AM and Baumgartner $\mathrm{G}, 2012$. Effects of abiotic variables on the distribution of fish assemblages in streams with different anthropogenic activities in Southern Brazil. Neotrop. Ichthyol. 10(3). https://doi.org/10.1590/S167962252012000300018

Eriegha OJ and Ekokotu PA, 2017. Factors affecting feed intake in cultured fish species: A Review. Anim. Res. Int. 14(2): 2697-2709.

Ezeabasili ACC, Okoro BU and Ezeabasili AI, 2014. Water Resources: Management and strategies in Nigeria. AFRREV STECH, An Int. J. Sci. Technol. 3(1): 35-54.

Francis MP, Morrison MA, Leathwick J, Walsh C and Middleton C, 2005. Predictive models of small fish presence and abundance in northern New Zealand harbours. Estuarine, Coastal and Shelf Sci. 64: 419-435. DOI: 10.1016/j.ecss.2005.03.007

Greshishchev V, Onikura N and Iyooka H, 2015. Environmental factors influencing fish species distribution in irrigation channels around Ariake Sea, Kyushu, Japan. Irrig. Drain. Syst. Eng. 4: 139. doi: 10. 4172/21689768.1000139.

Idodo-Umeh G, 2003. Freshwater fishes of Nigeria: Taxonomy, ecological notes, diet and utilization. Idodo-Umeh Publishers Limited, Benin City, Nigeria. p. 231.

Idu AJ, 2015. Threats to Water Resources Development in Nigeria. J. Geol. Geophys. 4(3): 
Agatha Arimiche Nwabueze and Emmanuel Obiajulu Nwabueze

205-214. DOI: 10.4172/2329-6755.1000205

Jisr N, Younes G, Sukhn C and El-Dakdouki MH, 2018. Length-weight relationships and relative condition factor of fish inhabiting the marine area of the Eastern Mediterranean city, TripoliLebanon. Egypt. J. Aquat. Res. 44(4): 299-305. https://doi.org/10.1016/j.ejar.2018.11.004

Jobling M, 2008. Environmental factors and rates of development and growth. In book: Handbook of Fish Biology and Fisheries, Vol. 1, Fish Biology. DOI: $\quad$ 10.1002/9780470693803.ch5

Kakareko T, Zbikowski J and Zytkowicz J, 2005. Diet partitioning in summer of two syntopic neogobiids from two different habitats of the lower Vistula River, Poland. J. Appl. Ichthyol. 21: 292-295.

Kigbu AA, Imgbian TD and Yakub MM, 2014. Unconventional cultivable freshwater fish species: a potential tool for increased production in Nigeria. Global Sci. Res. J. 2(3):152-157.

LeCren ED, 1951. The length-weight relationship and seasonal cycle in gonad weight and condition in the Perch (Perca fluviatilis). J. Anim. Ecol. 20: 201-219.

Liker A, Freckleton RP and Székely T, 2013. The evolution of sex roles in birds is related to adult sex ratio. Nature Commun. 4: 1587. https://doi.org/10.1038/ncomms 2600

Lloret J, de Sola LG, Souplet A and Galzin R, 2002. Effects of large-scale habitat variability on condition of demersal exploited fish in the northwestern Mediterranean. ICES J. Marine Sci. 59(6): 1215-1227. DOI: 10.1006/jmsc.2002.1294

Mahavadiya D, Sapra D, Rathod V and Sarman V, 2018. Effect of biotic and abiotic factors in feeding activity in Teleost fish; a review. J. Entomol. Zool. Stud. 6(3): 387-390.

Mane AM, Pattanaik SS, Jadhav R and Jena AK, 2017. Pond coloration, interpretation and possible measures of rectification for sustainable aquacultural practice. Aquacult. Times. 3(30): 2017- 06

McKellar AE, Turcotte MM and Hendry AP, 2009. Environmental Factors Influencing Adult Sex Ratio in Trinidadian Guppies. Oecologia. 159 (4): 735-745.

Ngueku BB, 2015. Cultivable fish species of river awe, Nasarawa state, Nigeria. Int. J. Fauna Biol. Stud. 2 (2): 15-19.

Nsor CA, 2016. Environmental determinants influencing fish community structure and diversity in two distinct seasons among wetlands of Northern Region (Ghana). Int. J. Ecol. 2016: 1598701 DOI: https://doi.org/10.1155/2016/1598701

Nwabueze AA and Garba AA, 2015. Growth pattern and condition factor of Bagrus bayad from two rivers in Southern Nigeria. Global J. Biosci. Biotechnol. 4 (4): 330-334.

Nwokedi TC, Odumodu CU, Anyanwu JO and Ndikom OC, 2020. Gap analysis evaluation of Nigeria's fish demand and production: Empirical evidences for investment in and policy development for offshore mariculture practices. Int. J. Fish. Aquat. Stud. 8(3): 384-394.

Offem BO, Ikpi GU and Ada F, 2010. Fish culture Technologies in Cross River State Nigeria. Int. J. Trop. Agric. Food Syst. 4 (2): 113-121.

Oladosun OO and Oladosun GA and Hart AI, 2012. Some ecological factors of the tropical floodplain influencing the breeding and conservation of Gymnarchus niloticus

(Cuvier 1829): a review. In: 26th Annual Conference of the Fisheries Society of Nigeria (FISON), 28 Nov - 2 Dec 2011, Minna, Nigeria. pp. 193-200.

Oluwale FV, Ugwumba AAA and Ugwumba OA, 2019. Aspects of the biology of juvenile Aba, Gymnarchus niloticus (Curvier 1829) from Epe Lagoon, Lagos, Nigeria. Int. J. Fish. Aquat. Stud. 7(3): 267-274.

Oluwarore K, 2018. Nigeria: Importing fish amidst abundant ocean resources, the paradox of a nation. Earth journalism Network. A project of Interview of International Centre for Investigative Reporting, Nigeria.

Opadokun IO and Ajani EK, 2015. Some aspects of the reproductive biology of Gymnarchus niloticus Cuvier, 1829 (Knifefish) in Lekki Lagoon, Nigeria. Int. J. Fish. Aquat. Stud. 2(3): 166-170.

Peig J and Green AJ, 2009. New perspectives for estimating body condition from mass/length data: the scaled mass index as an alternative method. Oikos. 118(12): 1883-1891. dx.doi.org/10.1111/j.1600-0706.2009.17643.x

Peig $\mathrm{J}$ and Green AJ, 2010. The paradigm of body condition: a critical reappraisal of current methods based on mass and length. Funct. Ecol. 24(6): 1323-1332. dx.doi.org/10.1111/j.13652435.2010.01751.x.

Reed W, Barchard J, Hopson AJ, Jennes J and Yaro I, 1967. Fish and fisheries of Northern Nigeria. 
Edition 1, Ministry of Agriculture, Northern Nigeria. p. 32.

Riede K, 2004. Global register of migratory speciesfrom global to regional scales. Final Report of $\mathrm{R}$ and D- Project 80805081. Federal Agency for Nature Conservation, Bonn, Germany. p. 329.

Sowersby W, Gonzalez-Voyer A and Rogell B, 2020. Sex ratios deviate across killifish species without clear links to life history. Evol. Ecol. 34: 411-426.

Udoh AJ and Nyienakuna MG, 2008. Examining Socio Economic Characteristics and Adoption Trend of Artisanal Fishers of Akwa Ibom State in West Africa. J. Agric. Social Sci. 4: 141-146.

Villamagna AM and Murphy BR, 2010. Ecological and socio- economic impacts of invasive water hyacinth (Eichhornia crassipes): a review. Freshwater Biol. 55(2): $\quad$ 282-298. doi.org/10.1111/j.1365-2427.2009.02294.x

Wahl DH and Claramunt RM, 2000. The effects of abiotic and biotic factors in determining larval fish growth rates: A comparison across species and reservoirs. Transact. Am. Fish. Society. 129 (3): 835-851. Doi: 10.157/1548-86592000129

Yongo E, Outa N and Ngodhe SO, 2017. Effects of Water hyacinth (Eichhornia crassipes Solm) Infestation on water quality, fish species diversity and abundance in the Nyanza Gulf of Lake Victoria, Kenya. Int. J. Fish. Aquat. Res. 2(1): 810 .

\section{Contribution of Authors}

Nwabueze AA: Conceived the research idea, contributed in planning and logistics, data collection, analysis of data, interpretation of results and manuscript preparation

Nwabueze EO: Contributed in logistics, data collection and manuscript write up 